\title{
A Review of Membrane Distillation Process: - Before, During and After Testing
}

\author{
N.A.S.Muhamad', N.M.Mokhtar ${ }^{* 1}$, R.Naim², W.J. Lau' ${ }^{3}$ and A.F. Ismail ${ }^{3}$ \\ ${ }^{1}$ Faculty of Engineering Technology, Universiti Malaysia Pahang, Lebuhraya Tun Razak 26300 Kuantan, \\ Pahang, Malaysia \\ ${ }^{2}$ Faculty of Chemical Engineering and Natural Resources, Universiti Malaysia Pahang, Lebuhraya Tun Razak, \\ 26300 Kuantan, Pahang, Malaysia \\ ${ }^{3}$ Advanced Membrane Technology Research Centre (AMTEC), Universiti Teknologi Malaysia, 81310 Skudai, \\ Johor, Malaysia. \\ *Email:nadzirah@ump.edu.my
}

\begin{abstract}
Membrane Distillation (MD) has garnered much interest as a reassured technology in separation and purification processes. MD separation process used difference of vapor pressure between surfaces of porous hydrophobic membrane as a driving force. The process allows only transport of water vapour molecules through membrane pores. This paper focuses on expectation of MD treatment process primarily for readers who lack knowledge on membrane process. A brief overview of MD before treatment process is given which includes membrane materials, membrane preparation techniques, membrane characteristics, module, and configuration. Membrane performance during treatment process was highlighted. The major drawback of MD which is membrane fouling was also emphasized in this paper.
\end{abstract}

Keywords- Membrane distillation, fouling, separation, membrane, hydrophobic

\section{INTRODUCTION}

Transport processes of membrane are mainly isothermal with transmembrane hydrostatic pressure, concentration, electrical or chemical potentials as their driving forces [1]. On the contrary, membrane distillation (MD) is known as non-isothermal separation process. In MD process, difference in temperature between hot feed and cold permeate solutions induces vapor pressure difference over membrane surface (Eykens et al., 2017). The process separates liquid and vapor phase [2]. The term MD comes from resemblance of MD to conventional distillation as these processes involve vapor/liquid equilibrium (VLE) principle for liquid-liquid separation. Both these processes require supply of heat to feed solution in order to attain latent heat of vaporization, [3]. In general, research interest in MD is continuously increasing over the year with an average of $23 \%$ from $100 \mathrm{MD}$ articles yearly published particularly focuses on membrane engineering and result in many novel approaches for membrane production [2].

MD can be used as a method for non-volatiles solutes separation from a mixture of volatiles and non-volatiles solutes as only volatiles components can successfully pass through the membrane while membrane retained liquid feed together with dissolved components. Normally, water is the major volatile components recovered in permeate side as water has a low boiling point. Recently, aside from desalination process, MD has been widely explored in application of wastewater treatment involving produced water, textile wastewater, valuable components recovery from seawater or brine and rubber wastewater oil-water emulsion treatment [4]. Besides, MD can be used to remove organic compounds which are volatile from water as they are transferred more easily through pores of membrane compared to less volatile water molecules [2]. 
MD membrane is the main component of MD system where it is a medium for water vapor transfer and act as a barrier for direct liquid water transfer [5]. Polymeric material that are hydrophobic such as polypropylene (PP), polyvinylidene fluoride (PVDF) and polytetrafluoroethylene (PTFE) are usually used to fabricate conventional MD membranes. In order to prevent direct permeation of liquid through membrane pores, hydrophobicity is an important factor [6]. Hydrophobic commercial microfiltration (MF) membranes are not particularly optimized for MD; still it usage in MD process is widely implemented. Such optimization is needed to further enhance MD performance. Generally, during MD process, water vapor is formed at hot interface of feed solution-membrane. Water vapor is then transport through membrane pores and then condensed at cold-side of solution interface. Figure 1 illustrates MD separation process.
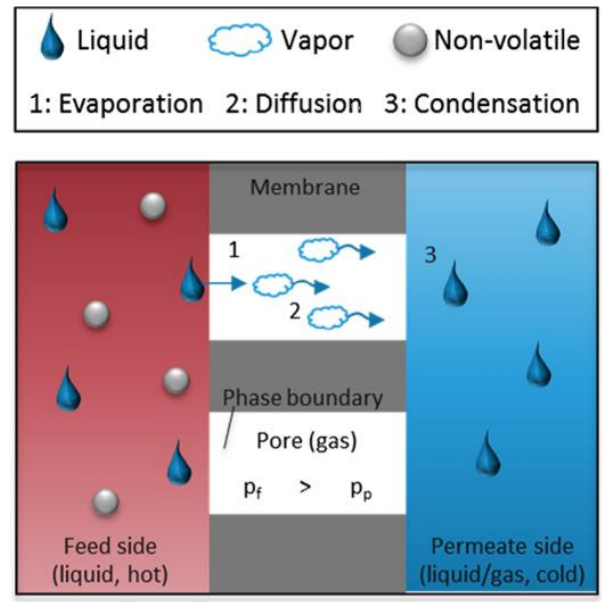

Figure 1: Illustration MD separation process [2]

There are several types of common MD configurations that used microporous hydrophobic membrane to distinguish aqueous feed solution [7] such as air gap membrane distillation (AGMD), direct contact membrane distillation (DCMD), vacuum membrane distillation (VMD) and sweeping gas membrane distillation (SGMD). Among these, DCMD is the most preferable type as it is easy to assemble and flexible to wide application. MD possesses substantial advantages over conventional separation technologies because of low temperature and hydrostatic pressure needed during the process [8]. Besides, there are no phase changes in MD and chemical additives are not needed. On the other hand, modular system that makes it easier to scale up [9], low energy consumption, less requirement of membrane mechanical properties [10]. Also high removal capacity of dissolved, non-volatile species and easy availability of membrane materials [11].

In this paper, expectation of MD treatment process is described primarily for the readers who have no idea about this membrane process. In the first part, a brief overview is given of MD before treatment process which includes membrane materials, membrane preparation techniques, membrane characteristics, membrane modules/housings, and MD configurations. Besides, membrane performance during treatment process was highlighted. Meanwhile, membrane fouling which is one of the main drawbacks of MD after separation process was also discussed.

\section{MEMBRANE MATERIALS}

In MD process, polymeric and inorganic membrane with hydrophobic properties can be used but, polymeric membranes especially have garner more attention as they have potential to modulate intrinsic properties [12]. In MD process, microporous membranes with hydrophobic properties are usually used and the most commonly used membranes are made either from PVDF, PTFE or PP [7,12]. The main reason for using these polymer is credit to their low surface tension [12]. It is believed that decrease in 
surface tension increased the membrane pore size and porosity. In general, order of increasing hydrophobicity of these polymers can be expressed as PVDF $<\mathrm{PP}<\mathrm{PTFE}$. Not only hydrophobic is the main factor in selecting the best MD membrane, but membranes also have to be porous with good stability in extreme temperatures and low thermal conductivity in order to prevent loss of heat throughout membrane matrix. Moreover, ideal MD membranes must have excellent chemical resistance (acids and bases) to feed solutions, low resistance to mass transfer and low fouling problem [13]. Membrane preparation techniques depend on material that will be used. Details about these membrane manufacturing procedures will be elaborated in the next section.

The applicable materials selected should fulfil certain criteria which include ease of fabrication and assembly, compatibility with other liquid, useful operating temperature and thermal conductivity [12]. As indicated previously, PTFE membranes are the most hydrophobic. It has exceptional chemical resistance and thermal stability properties. Besides, they are easy to dissolve in almost all common solvents. The downside of PTFE membranes is that it is usually prepared by stretching or sintering which is a difficult process [12]. Meanwhile, PP as the second best material behind PTFE demonstrates excellent solvent resistant properties and high crystallinity. However, it is usually fabricated by stretching and thermal phase inversion method that is complex in process [12]. PVDF membranes particularly have been utilized in membrane fabrication due to their high mechanical and chemical stability, good processability [14], better hydrophobicity and heat resistance [15]. In fact, this type of polymer can easily dissolve at room temperature in a variety of common solvents such as dimethylformamide (DMF). dimethylacetamide (DMAc) and N-methyl-2-pyrrolidone (NMP). It can be produced via a simple phase inversion method only [12].

\section{MEMBRANE PREPARATION TECHNIQUES}

There are several techniques for preparation of MD membrane including sintering, phase inversion, stretching, template leaching and track-etching [2]. Sintering, track-etching and template leaching are not suitable for MD process because fabricated membranes will have relatively low porosity. Conversely, high porosity membranes can be obtained via phase inversion and stretching method [2]. The techniques are chosen mainly depending on types of membrane materials and targeted application as indicated in Table 2. In practical ways, by choosing correct preparation method together with optimum process conditions, membrane properties can be modify to a certain extent.

\subsection{Phase Inversion}

Polymeric membrane are usually fabricated by technique of phase inversion $[3,16]$. The process separate homogenous system into two different phases comprise of a polymer, a solvent as well as other additives [17]. Phase inversion concept involve several techniques including precipitation by controlled evaporation, precipitation by solvent, precipitation from vapor phase, thermal precipitation and immersion precipitation or nonsolvent induced phase inversion [18].

In precipitation through solvent evaporation, an inert gas is used after the dope solution is cast for solvent to evaporate which consequently remove water vapor which then allows a membrane to be formed [18]. For precipitation by controlled evaporation, solvent and nonsolvent mixture is used in dissolving polymer. Due to high volatility of the solvent, evaporation process takes place. Membrane is formed due to the change of mixture content to a higher nonsolvent polymer content $[16,18]$. In thermally induced phase separation, dissolved polymeric solution is cooled down for separation to happen. Solvent evaporation commonly involves low molecular weight alcohol that induces membrane formation [3]. Microfiltration membranes are usually prepared using this technique [18].

In precipitation from vapour phase, a mixture of polymer and a solvent as dope solution is placed in a vapor atmosphere consisting of nonsolvent saturated with same solvent. Evaporation of solvent from cast film is prevented by high concentration of solvent in vapor phase [16]. Nonsolvent diffuse into cast film forming membrane. Phase inversion via nonsolvent induced phase inversion or immersion precipitation is frequently used method for preparation of membrane [16]. This method is performed by 
dissolving polymer in a solvent and homogenous polymeric solution is cast on an appropriate support before immersing in a coagulation bath consists of nonsolvent. Due to interchange between solvent and nonsolvent, precipitation occurs [18]. Mass transfer and phase separation process that take place result in formation of membrane structure [16]. By changing the type and amount of additives, polymer concentration and temperature, pore with variety of sizes can be obtained.

\subsection{Stretching}

In stretching method, a polymer of partial crystallinity, hollow fiber or film form, is perpendicularly stretched to the axis of crystallite orientation [17]. Polymer is extruded at a temperature just below its melting point combined with a rapid breakdown to produce a film. Mechanical stress is perpendicularly applied after annealing and cooling to the direction of the drawing. The process produced membrane with $90 \%$ relatively uniform porous structure and porosity (Khayet \& Matsuura, 2011). Common hydrophobic membrane such as PTFE, PP, and PE can be fabricated using this method.

\subsection{Sintering}

Sintering technique is generally utilized to fabricate ceramic or metallic membranes. This technique produced symmetric membranes. Powder of polymeric particles of a particular size is pressed and heated into a film or plate before sintering process take place, at or just below the melting temperature [3]. In this method, particles size and sintering profile are two main factors besides temperature, heating/cooling rates and dwelling time that affect pore size and porosity of the acquired membranes [17].

\subsection{Track etching}

Track-etching method produced membrane with uniform cylindrical pores. In this process, polymer matrix is damaged by introducing high-energy particle radiation to the thin dense polymer film. The damage polymer is then etched away in a solution containing an acid or alkaline. [17]. Membrane porosity is affected by residence time in the irradiation and is generally around $10 \%$ with pores dimensions within range $0.2-10 \mu \mathrm{m}$

\subsection{Template leaching}

Template leaching is suitable process to fabricate isotropic porous membranes from insoluble polymers or from glass, metal alloys and ceramics [17]. In this process, a mixture of polymer and a leachable component undergo homogenization, extrusion process and were pelletized a few times. After extrusion of the film, a suitable solvent is used for removal of leachable component. Microporous membrane is then formed [19].

\section{MEMBRANE CHARACTERISTICS}

The membrane ought to fulfil certain conditions before it can be applied in MD system. One of the requirements is that membrane should be made up of a single layer or multilayers with at least one made out of hydrophobic material and be porous [3]. Besides, membranes pore sizes must range in between $10 \mathrm{~nm}$ to $1 \mu \mathrm{m}$. Increase in pore size increase the permeate flux [12]. However, size of the pore should be as small as possible to avoid wettability and to make sure feed liquid cannot penetrate into the pores [1]. The tortuosity factor should be as small as possible [1,20]. Tortuosity refers to average length of pores against membrane thickness. Flux decreases as molecules travel throughout tortuous path where membrane pores do not form straight across the membrane. Therefore decrease in tortuosity increase the permeate flux [12]. Other than that, porosity is also one of the criteria. Membrane porosity is defined 
as volume of pores over total volume of membrane. Increase in membrane porosity level increase the evaporation surface area, resulting in higher permeate fluxes $[12,20]$ regardless of the MD configuration [3].

Membrane with befitting thickness are required since permeate flux decrease with an increase in membrane thickness [20]. Therefore, to obtain high permeate flux, membrane thickness must be as thin as possible [3]. In order that the heat loss is reduce, membrane material should possess low thermal conductivity $[3,12,20]$. Membrane surface that is in direct contact with feed solution should be fabricated with high fouling resistance material to avoid unnecessary fouling [1]. Membrane must also demonstrate good thermal stability $[1,20]$. Besides, it must possess good chemical resistance to variety of feed solutions $[1,20]$. Finally, membrane should have a long lifespan with a stable MD performance $[1,20]$.

\section{MEMBRANE MODULE USED IN MD PROCESS}

A membrane module is described as a device that is a combination of membrane with another to form a whole functional package. This include membrane mounting, a housing, flow channels with inlets, outlets and mountings respectively [21]. There is four commonly used membrane module which are hollow fiber, plate and frame, spiral wound and tubular [22].

\subsection{Hollow fiber membrane module}

Hollow fiber membrane module consists of two system, inside-outside and outside-inside system. In inside-outside system, feed solution passes through lumen of hollow fiber and permeate is collected outside of membrane fiber. While for outside-inside system, feed solution passes from outside hollow fibers and the permeate is collected inside the hollow fiber [7]. Hollow fiber membrane have high membrane area to modulate volume ratios and this make it more favorable in fabrication of membrane modules [23]. Hollow fiber membrane was more appealing because of its large specific surface area, low boundary layer resistance and high membrane packing density due to small strand diameter [24]. However, irreversible fouling and easy breakage are main problems concerning this type of membrane module.

The polymer used was dried before dissolved in a solvent and additive forming dope solution. Common solvents used to prepare hollow fiber membrane are DMF, DMAc, and NMP. To avoid any lump formation, polymer was added in small amount at a time to solvent mixture and continuously stirred overnight using overhead mechanical stirrer. A dry-wet jet spinning process are usually used to produce hollow fiber membranes by technique of non-solvent induced phase inversion [25,26]. Membrane was then immersed in coagulation bath to remove any residual solvents [25]. Thereafter, membrane was left to dry before tests.

\subsection{Plate and Frame module}

The plate and frame module were based on plate and frame filter press [27]. In plate and frame membrane systems membranes laid on top of a plate-like structure that is held together by frame-like support. The main advantages of plate and frame membrane system are an easy separation of solids from water and membrane can replace and clean more easily. However, there are several problems for plate and frame membrane systems which are low packing density, high-pressure drop, and low efficiency compare to other configurations.

Plate and frame module used flat sheet membrane in their configurations [21]. Flat membrane is made by dissolving a polymer in an appropriate solvent mixture and wait until it becomes a homogeneous dope solution. Then, dope solution is poured directly to a thin film using one of the supporting layer for casting ([18]. As it is easy to clean and replace, flat sheet membrane configuration has been used extensively on a laboratory scale [7]. 


\subsection{Spiral wound membrane module}

Spiral-wound elements composed of a combination of membranes, feed spacers, permeate spacers, and a permeate tube enveloped and rolled around a perforated central collection tube forming a cylindrical module. The feed solution passes over membrane and permeate spiral to the center collection tube $[7,28]$. The advantages of this module are that it comes in multiple configurations with different spacers, membrane type, lengths and diameters that allow it to fit multiple applications. These membrane modules have a very high packing density greater than that of plate and frame, tubular, and capillary configurations. Besides, cleaning can be done easily through cleaning in place. However, fouling occurred is more than fouling in tubular filtration processes. Spiral elements also cannot handle mechanical cleaning like tubular elements and contain lower packing density than hollow fiber.

\subsection{Tubular membrane}

In this module, membrane is tube-shaped and is fixed in the middle of hot and cold fluid cylindrical chambers [7]. Tubular membrane filtration works by pressuring feeding water into membrane tube. This pressure forces only water through membrane. The suspended particles exit tube and return back. Fouling occurred in tubular systems is less than plate and frame, but is similar when compared to spiral and capillary. Methods of robust cleaning such as use of harsh chemicals, mechanical cleaning and backwash can be used in tubular systems. The disadvantages of tubular modules are its large size and low packing density. The packing density of tubular module is higher compared to plate and frame systems but lower than hollow fiber, capillary and spiral wound elements. Besides, tubular required higher flow due to its large inner diameter compared to other system configurations.

\section{MEMBRANE CONFIGURATION}

\subsection{Direct Contact Membrane Distillation (DCMD)}

In this configuration, feed and permeate solution are in direct contact with membrane surfaces throughout the entire operation. Hydrophobic characteristics of membrane serve as a physical barrier and holds liquid-vapor phase at membrane pores. Cold permeate solution and hot feed solution comes into contact with membrane surface, resulting in a pressure difference across membrane. Permeation of water vapor and volatile species occurs through pores of membrane [5]. Inside membrane module, both condensation and evaporation processes occur at the same [29]. Among difference type of MD configurations, DCMD process is widely used in desalination processes and in food industries, or acid manufacturing [7]. Besides that, DCMD is employed in industrial wastewater treatment such as olive mill wastewater [30], fermentation wastewater [31], dyeing wastewater [29,32], radioactive wastewater [33-35] and pharmaceutical wastewater [4]. DCMD applications mostly still only in laboratory or small pilot plant phase up to this time [7].

\subsection{Air Gap Membrane Distillation (AGMD)}

In AGMD, membrane and the cooled condensation surface is separated by a thin layer of air. The air gap and condensation plate prevents permeated vapour to be in direct contact with cooling water, which in turn limits heat transfer rate from hot feed side to the cooling water [36]. The evaporation channel in AGMD resembles the one in DCMD. Membrane is separated from cold walling by permeate gap filled with air. For condensation to occur, vapor that permeates through membrane must overcome this air gap. AGMD has been utilized for desalination process [37], boron removal from geothermal water [38], heavy metal removal from wastewater [39] and treatment of produced water [40]. 


\subsection{Sweeping Gas Membrane Distillation (SGMD)}

SGMD uses an air stream to collect vapor. To avoid membrane pores wetting, membranes used in SGMD possess hydrophobic properties and microporous. In SGMD, feed solution is heated up reaching the suitable temperature before transferring to membrane surface. The volatile compounds permeate through membrane pores to permeate side where carrier gas collects and transfer vapor for further process. Meantime, non-volatile compounds get concentrated and would recirculate back to the feed tank [41]. SGMD is useful in removing volatile compounds from aqueous solution. It have been used for removal of water from dilute glycerol-water solution [42], treatment of triethylene glycol wastewater [41] and removal of ammonia from wastewater [43].

\subsection{Vacuum Membrane Distillation (VMD)}

In this configuration, cold permeate is substituted with vacuum, thus there are no resistance by the permeate [13]. Feed solution is brought into direct contact with porous hydrophobic membrane [44]. Condensation process occurs outside the membrane module. VMD is used to separate aqueous volatile solutions [7]. This configuration has been used in various MD applications such as for removal of dye from textile wastewater [45], water recovery from produced wastewater [46], removal of antibiotics from pharmaceutical wastewater [4], strontium ions and cobalt ions removal from radioactive wastewater [34,47] and recovery of polyphenols from olive mill wastewater [30]. Table 1 shows schematic diagram of each MD configuration and their advantages and disadvantages. 
Table 1: Configurations and their advantages and disadvantages

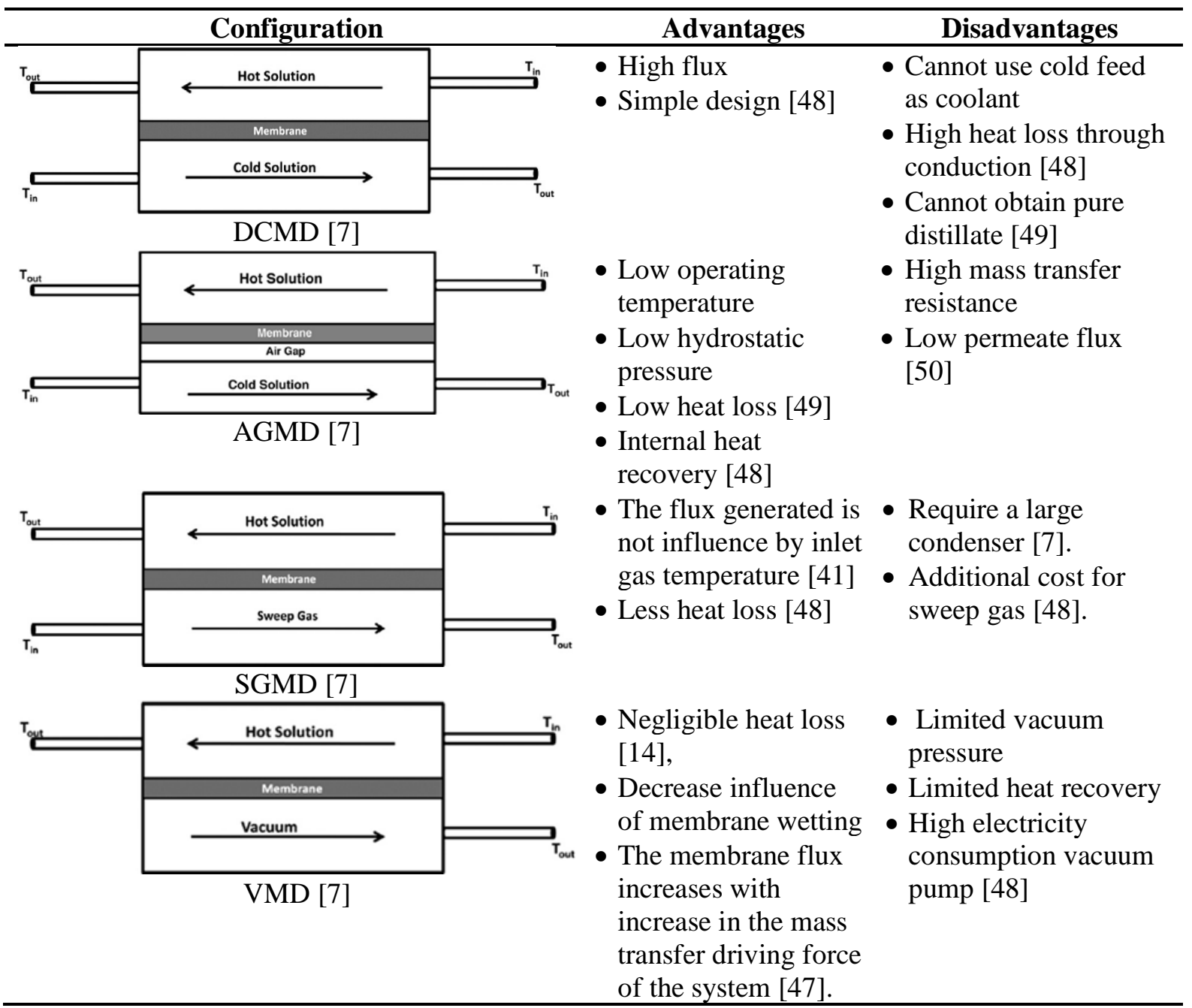


Table 2: Overview of the membrane distillation process in previous studies

\begin{tabular}{|c|c|c|c|c|c|c|c|c|c|}
\hline & $\begin{array}{l}\text { Membrane } \\
\text { module }\end{array}$ & Polymers & Solvents & Additives & $\begin{array}{c}\text { Membrane } \\
\text { preparation } \\
\text { technique }\end{array}$ & $\begin{array}{c}\text { MD } \\
\text { configuration }\end{array}$ & Objectives & Performances & References \\
\hline 1 & $\begin{array}{l}\text { Hollow } \\
\text { fiber }\end{array}$ & PVDF & NMP & EG & $\begin{array}{l}\text { Phase } \\
\text { inversion (dry- } \\
\text { wet jet } \\
\text { spinning } \\
\text { inversion) }\end{array}$ & VMD & $\begin{array}{l}\text { Purification of diluted } \\
\text { liquid desiccants }\end{array}$ & $\begin{array}{l}\text { Desalinated water } \\
\text { collected has a very low } \\
\text { salt concentration }\end{array}$ & [26] \\
\hline 2 & $\begin{array}{l}\text { Hollow } \\
\text { fiber }\end{array}$ & PVDF & $\begin{array}{l}\text { NMP, } \\
\text { NMP- } \\
\text { TEP \& } \\
\text { TEP }\end{array}$ & - & $\begin{array}{l}\text { Phase } \\
\text { inversion (dry- } \\
\text { jet wet } \\
\text { spinning } \\
\text { process) }\end{array}$ & DCMD & $\begin{array}{l}\text { Fabricate highly porous } \\
\text { membrane using non-toxic } \\
\text { solvent }\end{array}$ & $\begin{array}{l}\text { Membrane fabricated } \\
\text { have porosity higher than } \\
80 \%\end{array}$ & {$[25]$} \\
\hline 3 & $\begin{array}{l}\text { Hollow } \\
\text { fiber }\end{array}$ & PP & - & - & - & $\begin{array}{l}\text { AGMD, } \\
\text { PGMD }\end{array}$ & $\begin{array}{l}\text { AGMD and PGMD process } \\
\text { was compared }\end{array}$ & $\begin{array}{l}\text { Salt rejection was greater } \\
\text { than } 99.8 \% \text { in all } \\
\text { experiment }\end{array}$ & {$[51]$} \\
\hline 4 & $\begin{array}{l}\text { Hollow } \\
\text { fiber }\end{array}$ & PVDF & - & - & $\begin{array}{l}\text { Non-solvent } \\
\text { induced phase } \\
\text { separation } \\
\text { process }\end{array}$ & $\begin{array}{l}\text { PGMD, } \\
\text { DCMD, } \\
\text { SGMD }\end{array}$ & $\begin{array}{l}\text { PGMD, DCMD and } \\
\text { SGMD process was } \\
\text { compared }\end{array}$ & $\begin{array}{l}\text { PGMD has lower STEC } \\
\text { compared to SGMD and } \\
\text { DCMD when flux is } \\
\text { equal }\end{array}$ & {$[52]$} \\
\hline 5 & $\begin{array}{l}\text { Hollow } \\
\text { fiber }\end{array}$ & $\begin{array}{l}\text { PVDF- } \\
\text { HFP }\end{array}$ & $\begin{array}{l}\text { DMAc } \\
\& \text { TMP }\end{array}$ & PEG & $\begin{array}{l}\text { Phase } \\
\text { inversion } \\
\text { (Wet-wet } \\
\text { spinning } \\
\text { technique) }\end{array}$ & DCMD & $\begin{array}{l}\text { Effect of the corrugation } \\
\text { size and shape on DCMD } \\
\text { process }\end{array}$ & $\begin{array}{l}\text { Salt rejection factor was } \\
\text { greater than } 99.9 \%\end{array}$ & {$[53]$} \\
\hline 6 & $\begin{array}{l}\text { Hollow } \\
\text { fiber }\end{array}$ & $\begin{array}{l}\text { PVDF- } \\
\text { HFP }\end{array}$ & $\begin{array}{l}\text { DMAc } \\
\& \text { TMP }\end{array}$ & PEG & $\begin{array}{l}\text { Phase } \\
\text { inversion (dry- } \\
\text { wet spinning } \\
\text { technique) }\end{array}$ & DCMD & $\begin{array}{l}\text { Change of the outer layer } \\
\text { structure was observed }\end{array}$ & $\begin{array}{l}\text { HF with } 50 \% \text { wt DMAc } \\
\text { has the highest permeate } \\
\text { flux with good salt } \\
\text { rejection factor }\end{array}$ & {$[54]$} \\
\hline 7 & $\begin{array}{l}\text { Hollow } \\
\text { fiber }\end{array}$ & PTFE & - & - & Stretching & DCMD & $\begin{array}{l}\text { Compose stretching } \\
\text { conditions to integrate } \\
\text { membrane with high } \\
\text { permeate flux and salt } \\
\text { rejection }\end{array}$ & $\begin{array}{l}\text { Rejection rate of salt was } \\
\text { high up to } 99.99 \% \text { for } \\
\text { membrane fabricated at } \\
\text { stretching ratio } 2.4\end{array}$ & {$[55]$} \\
\hline
\end{tabular}


(Continued)

8 Hollow

fiber \& flat

sheet

\begin{tabular}{|c|c|c|c|c|c|}
\hline $\begin{array}{l}\text { Hollow } \\
\text { fiber }\end{array}$ & $\begin{array}{l}\text { PDMS \& } \\
\text { PVDF }\end{array}$ & $\begin{array}{l}\text { DMAc, } \\
\text { TEP \& } \\
\text { THF }\end{array}$ & PVP & $\begin{array}{l}\text { Non-solvent } \\
\text { induced phase } \\
\text { separation }\end{array}$ & VMD \\
\hline $\begin{array}{l}\text { Spiral } \\
\text { wound } \\
\text { (flat sheet) }\end{array}$ & PTFE & - & - & - & DCMD \\
\hline $\begin{array}{l}\text { Plate \& } \\
\text { frame (flat } \\
\text { sheet) }\end{array}$ & PVDF & NEP & $\mathrm{LiCl}$ & $\begin{array}{l}\text { Phase } \\
\text { separation }\end{array}$ & DCMD \\
\hline $\begin{array}{l}\text { Spiral } \\
\text { wound } \\
\text { (flat sheet) }\end{array}$ & PTFE & - & - & - & PGMD \\
\hline $\begin{array}{l}\text { Spiral } \\
\text { wound } \\
\text { (flat sheet) }\end{array}$ & PTFE & - & - & - & PGMD \\
\hline
\end{tabular}

14 Plate \&

frame (flat

sheet)

15 Plate \&
frame (flat

sheet)

PVDF

DMAc

LiCl \&
PEG

16 Plate \&

frame (flat

sheet)
Wet phase

inversion

process

DCMD

Performance of flat sheet membrane with high flux

DCMD

-
Phase
inversion
precipitation
method
membrane and $\mathrm{HF}$ at high temperature

Production of HF

Optimization of DCMD module operation

Comparison of

polyelectrolyte in

thermopervaporation with the porous membrane

Desalination process

Desalination process

Influence of nano-particles on membrane properties

Effect of membrane structure and operational variables on distillate production rate

Effect of $\mathrm{SiO}_{2}$ on PVDF membrane performance
Flat sheet and $\mathrm{HF}$ membrane achieved desalination without any salt leakage

High salt rejection of over $99.9 \%$ under optimum conditions

$-$

Membrane showed a high permeate rate for water

High salt rejection rate

Distillate output increased while the thermal energy demand reduced with an increase in dearation effort

Exhibit satisfying performance stability and obtain maximum

transmembrane permeate flux of $49.37 \mathrm{~kg} / \mathrm{m} 2 . \mathrm{h}$

Obtain salt rejection rate of more than $99.98 \%$ 
(Continued)

17 Tubular

PTFE

(flat sheet)

18 Tubular

$\mathrm{Al}_{2} \mathrm{O}_{3}$

19 Spiral

wound

20 Hollow

fiber

PVDF

fiber

22 Hollow

fiber

23 Hollow

fiber

PTFE \& - $\quad-$

PVDF

PVDF

NMP

PVDF

NMP

EG

Phase

inversion

Phase

inversion (dry-

jet wet

spinning

technique)

24 Hollow
fiber

PP

Hollow

25 Hollow

PP

fiber
AGMD \& Investigate permeate flux

DCMD of finned tubular AGMD

module

VMD

Effect of membrane

thickness and pore size on

water flux and salt rejection

rate

Water recovery

AGMD

DCMD

Treatment of wastewater

from rubber processing

effluent

DCMD Treatment of industrial

dyeing wastewater

DCMD

DCMD

Water recovery from hot

dyeing solution

Treatment of industrial

textile wastewater for clean

water production

DCMD

Treatment of fermentation

wastewater with high

organic concentrations

Recovery of water and

minerals from shale gas

produced water
High permeate flux

obtained in the proposed

AGMD-based finned

tubular membrane

module

High permeate flux

$30 \mathrm{~kg} / \mathrm{m} 2 . \mathrm{h}$ ) and salt

rejection rate $(99.99 \%)$

$95 \%$ water recovery

Permeate produced is of

high quality with $95 \%$

removal efficiency of

TOC, TDS, sulfate,

color, turbidity,

conductivity

Excellent rejection under

mild temperature and

limited pressure obtained

Excellent dye rejection

rate with $99.78 \%$

Excellent results in

eliminating almost all

dye components

$95 \%$ COD, TOC and

protein rejection rate

Water and mineral

recovered with low

energy consumption 


\section{EFFECT OF PROCESS PARAMETER ON MEMBRANE PERFORMANCE}

\subsection{Effect of feed temperature}

Feed temperature highly influences permeate flux [7,12].Vapor pressure increase with increase in temperature. Therefore, permeate flux is affected by the operating temperature. At constant temperature difference, increase in hot solution temperature increase the permeate flux. This indicates that permeate flux relies on hot fluid temperature [7]. Table 3 displays on previous studies carried out at different feed temperature and operating conditions.

Table 3: Effect of feed temperature on permeate flux

\begin{tabular}{|c|c|c|c|c|c|c|c|}
\hline & $\begin{array}{l}\text { MD } \\
\text { configuration }\end{array}$ & $\begin{array}{l}\text { Membrane } \\
\text { type }\end{array}$ & Feed & $\begin{array}{l}\text { Operating } \\
\text { condition }\end{array}$ & $\mathbf{T}_{\mathrm{f}}\left({ }^{\circ} \mathbf{C}\right)$ & $\begin{array}{l}\text { Permeate } \\
\left(\mathrm{kg} / \mathrm{m}^{2} . \mathrm{h}\right)\end{array}$ & Referances \\
\hline 1 & DCMD & $\begin{array}{l}\text { PTFE, } \\
\text { PP,PVDF }\end{array}$ & $\begin{array}{l}\text { Industrial } \\
\text { wastewater }\end{array}$ & $\begin{array}{l}\mathrm{V}=1 \mathrm{~L} / \mathrm{min} \\
\mathrm{pH}=3-11.5\end{array}$ & $30-70$ & $\begin{array}{l}\approx 2-52 \\
\mathrm{~kg} / \mathrm{m}^{2} . \mathrm{h}\end{array}$ & [70] \\
\hline 2 & AGMD & PTFE & $\begin{array}{l}\text { Produced } \\
\text { water }\end{array}$ & $\begin{array}{l}\mathrm{V}=0.5- \\
1.89 \mathrm{~L} / \mathrm{min}\end{array}$ & $40-80$ & $\approx 1-7 \mathrm{~g} / \mathrm{m}^{2} . \mathrm{s}$ & [40] \\
\hline 3 & SGMD & PTFE & $\begin{array}{l}\text { Wastewater } \\
\text { containing } \\
\text { ammonia }\end{array}$ & $\begin{array}{l}\mathrm{V}=250 \mathrm{~mL} / \mathrm{min} \\
\mathrm{pH}=11.5\end{array}$ & $50-70$ & $\begin{array}{l}\approx 5-15 \\
\mathrm{~kg} / \mathrm{m}^{2} . \mathrm{h}\end{array}$ & [43] \\
\hline 4 & VMDC & PP & $\begin{array}{l}\text { Simulated } \\
\text { radioactive } \\
\text { wastewater }\end{array}$ & $\mathrm{V}=41.8 \mathrm{~L} / \mathrm{h}$ & $30-70$ & $\begin{array}{l}\approx 0.2-7 \\
\mathrm{~L} / \mathrm{m}^{2} . \mathrm{h}\end{array}$ & [33] \\
\hline 5 & VMD & PP & $\begin{array}{l}\text { Simulated } \\
\text { radioactive } \\
\text { wastewater }\end{array}$ & $\begin{array}{l}\mathrm{V}=41.8 \mathrm{~L} / \mathrm{h} \\
\mathrm{P}=0.98 \mathrm{~atm}\end{array}$ & $30-70$ & $\begin{array}{l}\approx 0.5-6 \\
\mathrm{~L} / \mathrm{m}^{2} . h\end{array}$ & [47] \\
\hline 6 & DCMD & PVDF & $\begin{array}{l}\text { Boron } \\
\text { solution }\end{array}$ & $\begin{array}{l}\mathrm{V}_{\mathrm{f}}=60 \mathrm{~L} / \mathrm{h} \\
\mathrm{V}_{\mathrm{p}}=65 \mathrm{~L} / \mathrm{h} \\
\mathrm{pH}=6.5-8.5\end{array}$ & $30-80$ & $\begin{array}{l}\approx 3-35 \\
\mathrm{~kg} / \mathrm{m}^{2} . \mathrm{h}\end{array}$ & [15] \\
\hline 7 & DCMD & PVDF & $\begin{array}{l}\text { Arsenic } \\
\text { solution }\end{array}$ & $\begin{array}{l}\mathrm{T}_{\mathrm{p}}=20 \\
\mathrm{~V}_{\mathrm{p}}=0.10 \mathrm{~m} / \mathrm{s}\end{array}$ & $40-70$ & $\begin{array}{l}\approx 3-21 \\
\mathrm{~kg} / \mathrm{m}^{2} . \mathrm{h}\end{array}$ & [71] \\
\hline
\end{tabular}

\subsection{Effect of $p H$}

Hou et al. [15] in their study stated that feed $\mathrm{pH}$ does not greatly influence permeate flux and rejection of boron. MD is less dependence on feed $\mathrm{pH}$ as it driving force is temperature gradient exists on membrane surfaces. Therefore, higher rejection of boron can be achieved throughout DCMD process no matter the feed is either alkali or acid [15]. In another study, the results show that solution $\mathrm{pH}$ in weak alkaline and acidic medium did not influence ion rejection rate during DCMD process [71]. Table 3 illustrates effect of $\mathrm{pH}$ on permeate flux from previous studies.

Table 4: Effect of $\mathrm{pH}$ on permeate flux

\begin{tabular}{|c|c|c|c|c|c|c|c|}
\hline & $\begin{array}{l}\text { MD } \\
\text { configuration }\end{array}$ & $\begin{array}{l}\text { Membrane } \\
\text { type }\end{array}$ & Feed & $\begin{array}{l}\text { Operating } \\
\text { condition }\end{array}$ & pH & $\begin{array}{l}\text { Permeate } \\
\left(\mathrm{kg} / \mathrm{m}^{2} . \mathbf{h}\right)\end{array}$ & Referances \\
\hline 1 & DCMD & $\begin{array}{l}\text { PTFE, } \\
\text { PP,PVDF }\end{array}$ & $\begin{array}{l}\text { Industrial } \\
\text { wastewater }\end{array}$ & $\begin{array}{l}\mathrm{V}=1 \mathrm{~L} / \mathrm{min} \\
\mathrm{T}_{\mathrm{p}}=20^{\circ} \mathrm{C} \\
\mathrm{T}_{\mathrm{f}}=60^{\circ} \mathrm{C}\end{array}$ & $3-11.5$ & $\begin{array}{l}\approx 10-39 \\
\mathrm{~kg} / \mathrm{m}^{2} . \mathrm{h}\end{array}$ & [70] \\
\hline 2 & DCMD & PVDF & $\begin{array}{l}\text { Boron } \\
\text { solution }\end{array}$ & $\begin{array}{l}\mathrm{V}_{\mathrm{f}}=60 \mathrm{~L} / \mathrm{h} \\
\mathrm{V}_{\mathrm{p}}=65 \mathrm{~L} / \mathrm{h} \\
\mathrm{T}_{\mathrm{f}}=50^{\circ} \mathrm{C} \\
\mathrm{T}_{\mathrm{p}}=20^{\circ} \mathrm{C}\end{array}$ & $3-11.0$ & $\begin{array}{l}\approx 3-35 \\
\mathrm{~kg} / \mathrm{m}^{2} . \mathrm{h}\end{array}$ & [15] \\
\hline
\end{tabular}




\begin{tabular}{|c|c|c|c|c|c|c|}
\hline 3 & DCMD & PVDF & $\begin{array}{l}\text { Arsenic } \\
\text { solution }\end{array}$ & $\begin{array}{l}\mathrm{T}_{\mathrm{p}}=20 \\
\mathrm{~V}_{\mathrm{p}}=0.10 \mathrm{~m} / \mathrm{s}\end{array}$ & 4,9 & $\begin{array}{l}\approx 3-21 \\
\mathrm{~kg} / \mathrm{m}^{2} \cdot \mathrm{h}\end{array}$ \\
\hline
\end{tabular}

\subsection{Effect of feed flow rate}

In MD, higher flow rate of feed leads to greater permeate flux [12]. This is supported by Alkhudhiri et al. [40] in their study for treatment of produced water using AGMD. Different feed flow rates were investigated on production of permeate flux. Result obtained show that increase in feed flow rate leads to an increase in the permeate flux. This can be illustrated by phenomena of temperature and concentration polarization. Shearing forces generated at high flow rate reducing thickness of hydrodynamic boundary and thus reducing polarization effect. Hence, at the bulk feed solution, concentration and temperature at the liquid-vapor interface become closer to the corresponding values [12]. Table 5 shows effect of flow rate on permeate flux based on previous studies.

Table 5: Effect of flow rate on permeate flux

\begin{tabular}{|c|c|c|c|c|c|c|c|}
\hline & $\begin{array}{l}\text { MD } \\
\text { configuration }\end{array}$ & $\begin{array}{l}\text { Membrane } \\
\text { type }\end{array}$ & Feed & $\begin{array}{l}\text { Operating } \\
\text { condition }\end{array}$ & $\begin{array}{l}\text { Flow } \\
\text { rate }\end{array}$ & $\begin{array}{l}\text { Permeate } \\
\left(\mathrm{kg} / \mathbf{m}^{2} . \mathrm{h}\right)\end{array}$ & Referances \\
\hline 1 & AGMD & PTFE & $\begin{array}{l}\text { Produced } \\
\text { water }\end{array}$ & $\begin{array}{l}\mathrm{V}=0.5- \\
1.89 \mathrm{~L} / \mathrm{min}\end{array}$ & $\begin{array}{l}0.5- \\
1.89 \\
\mathrm{~L} / \mathrm{min}\end{array}$ & $\begin{array}{l}\approx 1.6-2.8 \\
\mathrm{~g} / \mathrm{m}^{2} . \mathrm{s}\end{array}$ & [40] \\
\hline 2 & SGMD & PTFE & $\begin{array}{l}\text { Wastewater } \\
\text { containing } \\
\text { ammonia }\end{array}$ & $\begin{array}{l}\mathrm{V}=250 \mathrm{~mL} / \mathrm{min} \\
\mathrm{pH}=11.5\end{array}$ & $\begin{array}{l}50-250 \\
\mathrm{~mL} / \mathrm{min}\end{array}$ & $\begin{array}{l}\approx 7-9 \\
\mathrm{~kg} / \mathrm{m}^{2} . \mathrm{h}\end{array}$ & [43] \\
\hline 3 & VMD & PP & $\begin{array}{l}\text { Simulated } \\
\text { radioactive } \\
\text { wastewater }\end{array}$ & $\begin{array}{l}\mathrm{V}=41.8 \mathrm{~L} / \mathrm{h} \\
\mathrm{P}=0.98 \mathrm{~atm}\end{array}$ & $\begin{array}{l}10.5- \\
41.8 \\
\mathrm{~L} / \mathrm{h}\end{array}$ & $\approx 4-6 \mathrm{~L} / \mathrm{m}^{2} \cdot \mathrm{h}$ & [47] \\
\hline 4 & DCMD & PVDF & $\begin{array}{l}\text { Arsenic } \\
\text { solution }\end{array}$ & $\begin{array}{l}\mathrm{T}_{\mathrm{p}}=20^{\circ} \mathrm{C} \\
\mathrm{V}_{\mathrm{p}}=0.10 \mathrm{~m} / \mathrm{s}\end{array}$ & $\begin{array}{l}0.23- \\
0.98 \mathrm{~m} / \mathrm{s}\end{array}$ & $\begin{array}{l}\approx 3-21 \\
\mathrm{~kg} / \mathrm{m}^{2} . \mathrm{h}\end{array}$ & [71] \\
\hline 5 & DCMD & PP,PTFE & $\begin{array}{l}\text { Synthetic } \\
\text { brackish } \\
\text { water }\end{array}$ & $\begin{array}{l}\mathrm{T}_{\mathrm{f}}=80^{\circ} \mathrm{C} \\
\mathrm{T}_{\mathrm{p}}=20^{\circ} \mathrm{C} \\
\mathrm{V}=4 \mathrm{~L} / \mathrm{min}\end{array}$ & $\begin{array}{l}1-4 \\
\mathrm{~L} / \mathrm{min}\end{array}$ & $\begin{array}{l}\approx 39-90 \\
\mathrm{~L} / \mathrm{m}^{2} \cdot \mathrm{h}\end{array}$ & [72] \\
\hline
\end{tabular}

\subsection{Effect of feed concentration}

The increase in feed concentration decreases permeate flux [7,12]. This may be due to lower vapor pressure of feed solution, driving force, with addition of non-volatile solute in water due to a decrease in water activity in the feed [3] and exponentially increase viscosity of feed with increasing concentration [12]. Effect of feed concentration on permeate flux was also investigated by Liu \& Wang [35]. They found that feed concentration in their study could affect vapor pressure of feed solution at liquid-vapor interface. Their results showed that permeate flux dropped linearly as salt concentration increased [35]. However, in a different study of the DCMD process of boron removal, permeate flux stabilized at about $10.5 \mathrm{~kg} / \mathrm{m}^{2}$ even though feed concentration increase [15]. It shows that feed concentration did not influence permeate flux. It can be said that MD can tolerate feed solution at high concentrations without suffering large drop in permeability [12]. 
Table 6: Effect of concentration on permeate flux

\begin{tabular}{|c|c|c|c|c|c|c|c|}
\hline & $\begin{array}{l}\text { MD } \\
\text { configuration }\end{array}$ & $\begin{array}{l}\text { Membrane } \\
\text { type }\end{array}$ & Feed & $\begin{array}{l}\text { Operating } \\
\text { condition }\end{array}$ & $\begin{array}{l}\text { Concentratio } \\
\mathrm{n}\end{array}$ & $\begin{array}{l}\text { Permeate } \\
\left(\mathrm{kg} / \mathrm{m}^{2} . \mathrm{h}\right)\end{array}$ & Referances \\
\hline 1 & VMDC & $\mathrm{PP}$ & $\begin{array}{l}\text { Simulated } \\
\text { radioactive } \\
\text { wastewater }\end{array}$ & $\begin{array}{l}\mathrm{V}=41.8 \\
\mathrm{~L} / \mathrm{h}\end{array}$ & $0-100 \mathrm{~g} / \mathrm{L}$ & $\begin{array}{l}\approx 6.2-5.5 \\
\mathrm{~L} / \mathrm{m}^{2} . \mathrm{h}\end{array}$ & [33] \\
\hline 2 & DCMD & PVDF & $\begin{array}{l}\text { Boron } \\
\text { solution }\end{array}$ & $\begin{array}{l}\mathrm{V}_{\mathrm{f}}=60 \mathrm{~L} / \mathrm{h} \\
\mathrm{V}_{\mathrm{p}}=65 \mathrm{~L} / \mathrm{h} \\
\mathrm{pH}=6.5- \\
8.5\end{array}$ & $0-5000 \mathrm{mg} / \mathrm{L}$ & $\begin{array}{l}\approx 10.5 \\
\mathrm{~kg} / \mathrm{m}^{2} . \mathrm{h}\end{array}$ & [15] \\
\hline \multicolumn{8}{|c|}{ (Continued) } \\
\hline 3 & DCMD & PP,PTFE & $\begin{array}{l}\text { Synthetic } \\
\text { brackish }\end{array}$ & $\begin{array}{l}\mathrm{T}_{\mathrm{p}}=20^{\circ} \mathrm{C} \\
\mathrm{T}_{\mathrm{f}}=80^{\circ} \mathrm{C} \\
\mathrm{V}=4 \mathrm{~L} / \mathrm{min}\end{array}$ & $\begin{array}{l}1000-10000 \\
\text { ppm }\end{array}$ & $\begin{array}{l}\approx 80-90 \\
\mathrm{~L} / \mathrm{m}^{2} . \mathrm{h}\end{array}$ & [72] \\
\hline 4 & DCMD & PVDF & & & $0-100 \mathrm{~g} / \mathrm{L}$ & $\begin{array}{l}\approx 7.25-4.75 \\
\mathrm{~L} / \mathrm{m}^{2} . \mathrm{h}\end{array}$ & [35] \\
\hline
\end{tabular}

\section{MEMBRANE FOULING}

Even though fouling phenomenon in MD is considerably less than those faced in other processes of pressure-driven membrane, but it is part of major disadvantages in membrane distillation that degrades membrane performances [22]. Theoretically, MD only allows water vapors to pass through membrane pores and has a $100 \%$ rejection rate of non-volatile compounds. Despite that, few factors among which poor long term hydrophobicity of materials, damage and degradation of membrane and membrane thickness can lead to fouling. Besides, existence of inorganic, organic macromolecules and microorganisms, colloidal and particulate in feed water could also lead to deposition of fouling substances which will negatively affect rejection efficiency and deteriorate performance of MD [10].

Membrane fouling pertains to the deposition or accumulation of suspended or dissolved substances on the membrane surface and/or within its pores that lead to deterioration of membrane performance [12]. Fouling occurred when unwanted substances comprise of biological and suspended particles, corrosion products as well as variety of crystalline deposits [8] attached themselves on membrane hydrophobic surface. The accumulation of more substances will ultimately increase net resistant to heat and mass transfer as a thick cake layer formed and result in flux decrease. Membrane heat and mass transfer depend on the fouling layer thickness [13]. Besides, foulant species could cause flux decay due to plugging at the entrance of membrane pore and eventually results in membrane pore wetting. Pores of the membrane are very small. Therefore, accumulation of fouling substances at the surface of membrane may cause pressure drop to increase to the point that hydrostatic pressure surpassing liquid entry pressure (LEP) of feed or permeate solution into membrane pores [8].

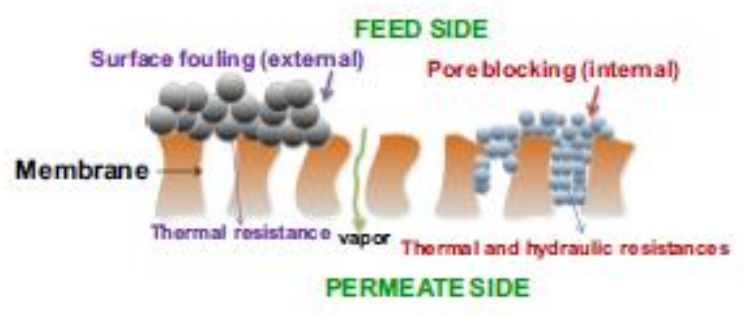

Figure 3: Schematic diagram of membrane fouling [10]

Commonly, fouling can be classified into four types; inorganic, organic, biological, and particulate or colloidal fouling [66]. Deposition of inorganic substances on the membrane surfaces or inside the pore 
structure causes inorganic fouling [12]. Organic fouling occurs when there are organic matters presence inside the pores or on membrane surface [12]. Particulate or colloidal fouling are formed when there is presence of solid particles on membrane surface [8]. Biological fouling usually occurred when feed solution used contain biological substances [66].

Wu et al. [31] stated that permeate flux decreased with time mainly because of membrane fouling. Organic and inorganic matters in feed wastewater block membrane pores by depositing on membrane inner surface, thus blocking the transfer of water molecules. Besides that, Cho et al. [73] reported that increase in temperature difference increases the initial flux rate lead to an increase in fouling rate. In another study, results show that presence of organic matters cause a slightly higher flux decline and a significant loss of membrane hydrophobicity [66,74].

Fouling is a persistent problem [10] and is the major drawback in MD which limits commercialization of full-scale plant [75]. Fouling reduce effective separation area, contributing to a permeate flow rate reduction, pore wetting and change in permeate water quality, membrane damage, increased temperature and concentration polarization and chemical degradation [76]. This will disrupt process operation as membrane need to be clean or replace, thus increases the operation cost. An early warning system that will detect the fouling problems in membranes processes is important to improvement of membrane operation and the development of a fouling strategy [22]. The main fouling prevention tools utilized in MD are feed pre-treatment and chemical cleaning [76]. It is said that first step to solving the fouling problem is to understand fouling phenomena and the processes involved.

\section{CONCLUSION}

MD has gained interest as a favourable alternative as substitution to other separation processes for its lower operating temperature and pressure, lower energy requirement than conventional distillation and higher rejection rate than in pressure driven process. It is said that MD process is a promising separation technique, but surprisingly the information regarding the process is still insufficient. Based on the knowledge acquired and gathered information on MD processes, a framework for better understanding of MD processes has been presented in this study. This framework is an attempt to highlight the expectation MD treatment process, before, during and after the test

\section{ACKNOWLEDGEMENT}

The authors gratefully acknowledge the Ministry of Education (MOE) for financial support via the Fundamental Research Grant Scheme (FRGS) Program under Universiti Malaysia Pahang (UMP) with the grant number RDU170118 and internal grant from UMP (RDU170315). Sincere gratitude also expressed to MOE Malaysia for the AMTEC fellowship program under UTM-HiCOE Research Grants (A.J090301.5300.07092) and to UMP for providing MRS scholarship.

\section{Nomenclature:}

$\begin{array}{ll}\text { AGMD } & \text { Air gap membrane distillation } \\ \mathrm{Al}_{2} \mathrm{O}_{3} & \text { Aluminium oxide } \\ \text { DCMD } & \text { Direct contact membrane distillation } \\ \text { DMAc } & \text { Dimethylacetamide } \\ \text { DMF } & \text { Dimethylformamide } \\ \text { EG } & \text { Ethylene glycol } \\ \text { LEP } & \text { Liquid entry pressure } \\ \text { LiCl } & \text { Lithium chloride } \\ \text { MD } & \text { Membrane distillation } \\ \text { MDC } & \text { Membrane distillation crystallization } \\ \text { MF } & \text { Microfiltration } \\ \text { NEP } & \text { N-ethyl-2-pyrolidone } \\ \text { NIPS } & \text { Nonsolvent induced phase separation }\end{array}$




$\begin{array}{ll}\text { NMP } & \text { N-methyl-2-pyrolidone } \\ \text { PE } & \text { Polyethylene } \\ \text { PEG } & \text { Polyethylene glycol } \\ \text { PGMD } & \text { Permeate gas membrane distillation } \\ \text { PP } & \text { Polypropylene } \\ \text { PTFE } & \text { Polytetrafluoroethylene } \\ \text { PVDF } & \text { Polyvinylidene fluoride } \\ \text { PVDF-HFP } & \text { poly(vinylidene fluoride-co-hexafluoropropylene } \\ \text { PVP } & \text { Polyvinylpyrrolidone } \\ \text { SGMD } & \text { Sweeping gas membrane distillation } \\ \text { SiO } & \text { Silicon dioxide } \\ \mathrm{TEG}_{\mathrm{TEP}} & \text { Triethylene glycol } \\ \mathrm{T}_{\mathrm{f}} & \text { Triethyl phosphate } \\ \mathrm{THF} & \text { Temperature feed } \\ \mathrm{TIPS} & \text { Tetrahydrofuran } \\ \mathrm{TMP} & \text { Thermally induced phase separation } \\ \mathrm{T}_{\mathrm{p}} & \text { Trimethyl phosphate } \\ \mathrm{V}_{\mathrm{f}} & \text { Temperature permeate } \\ \text { VMD } & \text { Flow rate feed } \\ \mathrm{V}_{\mathrm{p}} & \text { Vacuum membrane distillation } \\ \end{array}$

\section{REFERENCES}

[1] Khayet M Membranes and theoretical modeling of membrane distillation: A review, Adv. Colloid Interface Sci. 164 (2011) 56-88.

[2] Eykens L, De Sitter K, Dotremont C, Pinoy L, Van der Bruggen B, Membrane synthesis for membrane distillation: A review, Sep. Purif. Technol. 182 (2017) 36-51.

[3] Khayet M, Matsuura T, Membrane Distillation: Principles and Applications, 2011.

[4] Guo J, Farid M.U, Lee E.J, Yan D.Y.S, Jeong S, Kyoungjin An A, Fouling behavior of negatively charged PVDF membrane in membrane distillation for removal of antibiotics from wastewater, J. Memb. Sci. 551 (2018) 12-19.

[5] Qtaishat M, Khayer M, Matsuura T, Khulbe K.C, Effect of Casting Conditions on SMM Blended Polyethersulfone Hydro-Phobic / -Philic Composite Membranes: Characteristics and Desalination Performance in Membrane Distillation, 11 (2010) 1-8.

[6] Wang Z, Lin S, Membrane fouling and wetting in membrane distillation and their mitigation by novel membranes with special wettability, Water Res. 112 (2017) 38-47.

[7] Alkhudhiri A, Darwish N, Hilal N, Membrane distillation: A comprehensive review, Desalination. 287 (2012) 2-18.

[8] El-Bourawi M.S, Ding Z, Ma R, Khayet M. Khayet, A framework for better understanding membrane distillation separation process, J. Memb. Sci. 285 (2006) 4-29.

[9] Kang G-D, Cao Y-M, Application and modification of poly(vinylidene fluoride) (PVDF) membranes - A review, J. Memb. Sci. 463 (2014) 145-165.

[10] Tijing L.D, Woo Y.C, Choi J.S, Lee S, Kim S.H, Shon H.K, Fouling and its control in membrane distillation-A review, J. Memb. Sci. 475 (2015) 215-244.

[11] Jhaveri J.H, Murthy Z.V.P, A comprehensive review on anti-fouling nanocomposite membranes for pressure driven membrane separation processes, Desalination. 379 (2016) 137-154.

[12] Onsekizoglu P, Membrane Distillation: Principle, Advances, Limitations and Future Prospects in Food Industry, Distill. - Adv. from Model. to Appl. (2012).

[13] Drioli E, Ali A, Macedonio F, Membrane distillation: Recent developments and perspectives, Desalination. 356 (2015) 56-84.

[14] Cui Z, Zhang Y, Li X, Wang X, Drioli E, Wang Z, Zhao S, Optimization of novel composite membranes for water and mineral recovery by vacuum membrane distillation, Desalination. 440 (2018) 39-47. 
[15] Hou D, Wang J, Sun X, Luan Z, Zhao C, Ren X, Boron removal from aqueous solution by direct contact membrane distillation, J. Hazard. Mater. 177 (2010) 613-619.

[16] Kesting R.E, Phase inversion membranes, ACS Symp. Ser. ACS Symp. Ser. Vol 269. 269 (1985) 131-164.

[17] Figoli A, Simone S, Drioli E, Membrane fabrication, 2015.

[18] Ladewig B, Al-Shaeli M.N.Z, Fundamentals of Membrane Processes, (2017) 13-37.

[19] Baker R.W, Membranes and Modules, in: Membr. Technol. Appl., 2nd edition, John Wiley \& Sons Ltd, 2004: p. 96.

[20] Thi N, My T, Thi V, Nhi Y, Thanh B.X, Factors Affecting Membrane Distillation Process for Seawater Desalination, 22 (2018) 19-29.

[21] Winter D, Koschikowski J, Gross F, Maucher D, Düver D, Jositz M, Mann T, Hagedorn, A. Hagedorn, Comparative analysis of full-scale membrane distillation contactors - methods and modules, J. Memb. Sci. 524 (2017) 758-771.

[22] Tung K.L, Teoh H.C, Lee C.W, Chen C.H, Li Y.L, Lin Y.F, Chen C.L, Huang M.S, Characterization of membrane fouling distribution in a spiral wound module using highfrequency ultrasound image analysis, J. Memb. Sci. 495 (2015) 489-501.

[23] Huang A, Feng B. Feng, Synthesis of novel graphene oxide-polyimide hollow fiber membranes for seawater desalination, J. Memb. Sci. 548 (2018) 59-65.

[24] Zhang H, Li B, Sun D, Miao X, Gu Y, SiO2-PDMS-PVDF hollow fiber membrane with high flux for vacuum membrane distillation, Desalination. 429 (2018) 33-43.

[25] Chang J, Zuo J, Zhang L, O'Brien G.S, Chung T.S, Using green solvent, triethyl phosphate (TEP), to fabricate highly porous PVDF hollow fiber membranes for membrane distillation, J. Memb. Sci. 539 (2017) 295-304.

[26] Lefers R, Bettahalli N.M.S, Fedoroff N, Nunes S.P, Leiknes T.O, Vacuum membrane distillation of liquid desiccants utilizing hollow fiber membranes, Sep. Purif. Technol. 199 (2018) 57-63.

[27] Yang X, Wang R, Fane A.G, Tang C.Y, Wenten I.G, Membrane module design and dynamic shear-induced techniques to enhance liquid separation by hollow fiber modules: A review, Desalin. Water Treat. 51 (2013) 3604-3627.

[28] Curcio E, Drioli E, Membrane distillation and related operations - A review, Sep. Purif. Rev. 34 (2005) 35-86.

[29] Mokhtar N.M, Lau W.J, Ismail A.F, Youravong W, Khongnakorn W, Lertwittayanon K, Performance evaluation of novel PVDF-Cloisite 15A hollow fiber composite membranes for treatment of effluents containing dyes and salts using membrane distillation, RSC Adv. 5 (2015) 38011-38020.

[30] Carnevale M.C, Gnisci E, Hilal J, Criscuoli A, Direct Contact and Vacuum Membrane Distillation application for the olive mill wastewater treatment, Sep. Purif. Technol. 169 (2016) 121-127.

[31] Wu Y, Kang Y, Zhang L, Qu D, Cheng X, Feng L, Performance and fouling mechanism of direct contact membrane distillation (DCMD) treating fermentation wastewater with high organic concentrations, J. Environ. Sci. (China). 65 (2018) 253-261.

[32] Li F, Huang J, Xia Q, Lou M, Yang B, Tian Q, Liu Y, Direct contact membrane distillation for the treatment of industrial dyeing wastewater and characteristic pollutants, Sep. Purif. Technol. 195 (2018) 83-91.

[33] Jia F, Li J, Wang J. Wang, Recovery of boric acid from the simulated radioactive wastewater by vacuum membrane distillation crystallization, Ann. Nucl. Energy. 110 (2017) 1148-1155.

[34] IA F, Li J, Wang J, Sun Y, Annals of Nuclear Energy Removal of strontium ions from simulated radioactive wastewater by vacuum membrane distillation, Ann. Nucl. Energy. 103 (2017) 363368.

[35] Liu H, Wang J, Treatment of radioactive wastewater using direct contact membrane distillation, J. Hazard. Mater. 261 (2013) 307-315.

[36] Woldemariam D.M, District Heating-Driven Membrane Distillation for Water Purification in 
Industrial Applications, 2017.

[37] Alsalhy Q.F, Ibrahim S.S, Hashim F.A, Experimental and theoretical investigation of air gap membrane distillation process for water desalination, Chem. Eng. Res. Des. 130 (2018) 95-108.

[38] Ozbey-Unal B, Imer D.Y, Keskinler B, Koyuncu I, Boron removal from geothermal water by air gap membrane distillation, Desalination. 433 (2018) 141-150.

[39] Attia H, Alexander S, Wright C.J, Hilal N, Superhydrophobic electrospun membrane for heavy metals removal by air gap membrane distillation (AGMD), Desalination. 420 (2017) 318-329.

[40] Alkhudhiri A, Darwish N, Hilal N. Hilal, Produced water treatment: Application of Air Gap Membrane Distillation, Desalination. 309 (2013) 46-51.

[41] Minh P, Jacob P, Rattanaoudom R, Visvanathan C, Chemical Engineering and Processing: Process Intensi fi cation Feasibility of sweeping gas membrane distillation on concentrating triethylene glycol from waste streams, Chem. Eng. Process. Process Intensif. 110 (2016) 225234.

[42] Shirazi M.M.A, Kargari A, Tabatabaei M, Ismail A.F, Matsuura T, Concentration of glycerol from dilute glycerol wastewater using sweeping gas membrane distillation, Chem. Eng. Process. Process Intensif. 78 (2014) 58-66.

[43] Xie Z, Duong T, Hoang M, Nguyen C, Bolto B. Bolto, Ammonia removal by sweep gas membrane distillation, Water Res. 43 (2009) 1693-1699.

[44] A.I. and Chel-Ken Chiam R.S, Desalination in Cross-flow Vacuum Membrane Distillation under the Negative Membrane Pressure Difference.pdf, (2014).

[45] Baghel R, Upadhyaya S, Chaurasia S.P, Singh K, Kalla S, Optimization of process variables by the application of response surface methodology for naphthol blue black dye removal in vacuum membrane distillation, J. Clean. Prod. (2018).

[46] Yao M, Woo Y.C, Tijing L.D, Choi J.S, Shon H.K, Effects of volatile organic compounds on water recovery from produced water via vacuum membrane distillation, Desalination. 440 (2018) $146-155$.

[47] Jia F, Yin Y, Wang J. Wang, Removal of cobalt ions from simulated radioactive wastewater by vacuum membrane distillation, Prog. Nucl. Energy. 103 (2018) 20-27.

[48] Eykens L, Reyns T, De Sitter K, Dotremont C, Pinoy L, Van der Bruggen B, How to select a membrane distillation configuration- Process conditions and membrane influence unraveled, Desalination. 399 (2016) 105-115.

[49] Amaya-vías D, Nebot E, López-ramírez J.A, Comparative studies of di ff erent membrane distillation con fi gurations and membranes for potential use on board cruise vessels, Desalination. 429 (2018) 44-51.

[50] Alcheikhhamdon A.A, Darwish N.A, Hilal N, Statistical analysis of air-gap membrane desalination experimental data: Hypothesis testing, Desalination. 362 (2015) 117-125.

[51] Cheng L, Zhao Y, Li P, Li W, Wang F, Comparative study of air gap and permeate gap membrane distillation using internal heat recovery hollow fiber membrane module, Desalination. 426 (2018) 42-49.

[52] Gao L, Zhang J, Gray S, De Li J, Experimental study of hollow fiber permeate gap membrane distillation and its performance comparison with DCMD and SGMD, Sep. Purif. Technol. 188 (2017) 11-23.

[53] García-Fernández L, García-Payo C, Khayet M, Hollow fiber membranes with different external corrugated surfaces for desalination by membrane distillation, Appl. Surf. Sci. 416 (2017) 932946.

[54] García-Fernández L, García-Payo M.C, Khayet M, Mechanism of formation of hollow fiber membranes for membrane distillation: 2. Outer coagulation power effect on morphological characteristics, J. Memb. Sci. 542 (2017) 469-481.

[55] Li K, Zhang Y, Xu L, Zeng F, Hou D, Wang J, Optimizing stretching conditions in fabrication of PTFE hollow fiber membrane for performance improvement in membrane distillation, J. Memb. Sci. 550 (2018) 126-135. 
[56] Singh D, Sirkar K.K, Performance of PVDF flat membranes and hollow fibers in desalination by direct contact membrane distillation at high temperatures, Sep. Purif. Technol. 187 (2017) 264-273.

[57] Bell C.M, Comparison of polyelectrolyte coated PVDF membranes in thermopervaporation with porous hydrophobic membranes in membrane distillation using plate-and-frame modules, Chem. Eng. Process. Process Intensif. 104 (2016) 58-65.

[58] Winter D, Koschikowski J, Wieghaus M, Desalination using membrane distillation: Experimental studies on full scale spiral wound modules, J. Memb. Sci. 375 (2011) 104-112.

[59] Winter D, Koschikowski J, Ripperger S, Desalination using membrane distillation: Flux enhancement by feed water deaeration on spiral-wound modules, J. Memb. Sci. 423-424 (2012) 215-224.

[60] Hou D, Dai G, Fan H, Wang J, Zhao C, Huang H, Effects of calcium carbonate nano-particles on the properties of PVDF/nonwoven fabric flat-sheet composite membranes for direct contact membrane distillation, Desalination. 347 (2014) 25-33.

[61] Karanikola V, Corral A.F, Jiang H, Sáez A.E, Ela W.P, Arnold R.G, Effects of membrane structure and operational variables on membrane distillation performance, J. Memb. Sci. 524 (2017) 87-96.

[62] Efome J.E, Baghbanzadeh M, Rana D, Matsuura T, Lan C.Q, Effects of superhydrophobic $\mathrm{SiO}_{2}$ nanoparticles on the performance of PVDF flat sheet membranes for vacuum membrane distillation, Desalination. 373 (2015) 47-57.

[63] Cheng L.H, Lin Y.H, Chen J, Enhanced air gap membrane desalination by novel finned tubular membrane modules, J. Memb. Sci. 378 (2011) 398-406.

[64] Chen Y.R, Chen L.H, Chen C.H, Ko C.C, Huang A, Li C.L, Chuang C.J, Tung K.L, Hydrophobic alumina hollow fiber membranes for sucrose concentration by vacuum membrane distillation, J. Memb. Sci. 555 (2018) 250-257.

[65] Duong H.C, Chivas A.R, Nelemans B, Duke M, Gray S, Cath T.Y, Nghiem L.D, Treatment of RO brine from CSG produced water by spiral-wound air gap membrane distillation - A pilot study, Desalination. 366 (2015) 121-129.

[66] Mokhtar N.M, Lau W.J, Ismail A.F, Veerasamy D, Membrane distillation technology for treatment of wastewater from rubber industry in Malaysia, Procedia CIRP. 26 (2015) 792-796.

[67] Mokhtar N.M, Lau W.J, Ismail A.F, The potential of membrane distillation in recovering water from hot dyeing solution, J. Water Process Eng. 2 (2014) 71-78.

[68] Mokhtar N.M, Lau W.J, Ismail A.F, Kartohardjono S, Lai S.O, Teoh H.C, The potential of direct contact membrane distillation for industrial textile wastewater treatment using PVDF-Cloisite 15A nanocomposite membrane, Chem. Eng. Res. Des. 111 (2016) 284-293.

[69] Kim J, Kim J, Hong S, Recovery of water and minerals from shale gas produced water by membrane distillation crystallization, Water Res. 129 (2018) 447-459.

[70] Damtie M.M, Kim B, Woo Y.C, Choi J.S, Membrane distillation for industrial wastewater treatment: Studying the effects of membrane parameters on the wetting performance, Chemosphere. 206 (2018) 793-801.

[71] Qu D, Wang J, Hou D, Luan Z, Fan B, Zhao C, Experimental study of arsenic removal by direct contact membrane distillation, J. Hazard. Mater. 163 (2009) 874-879.

[72] Yarlagadda S, Gude V.G, Camacho L.M, Pinappu S, Deng S. Deng, Potable water recovery from As, U, and F contaminated ground waters by direct contact membrane distillation process, J. Hazard. Mater. 192 (2011) 1388-1394.

[73] Cho H, Choi Y, Lee S, Effect of pretreatment and operating conditions on the performance of membrane distillation for the treatment of shale gas wastewater, Desalination. 437 (2018) 195209.

[74] Naidu G, Jeong S, Choi Y, Vigneswaran S, Membrane distillation for wastewater reverse osmosis concentrate treatment with water reuse potential, J. Memb. Sci. 524 (2017) 565-575.

[75] Fortunato L, Jang Y, Lee J.G, Jeong S, Lee S, Leiknes T.O, Ghaffour N, Fouling development 
in direct contact membrane distillation: Non-invasive monitoring and destructive analysis, Water Res. 132 (2018) 34-41.

[76] Warsinger D.M, Swaminathan J, Guillen-Burrieza E, Arafat H.A, Lienhard V J.H, Scaling and fouling in membrane distillation for desalination applications: A review, Desalination. 356 (2015) 294-313. 